\title{
PENERAPAN MODEL PEMBELAJARAN KOOPERATIF TIPE THINK TALK WRITE ( TTW ) DALAM MENINGKATKAN KETERAMPILAN MENULIS SISWA KELAS VIII SMP NEGERI 1 LEMBANG
}

\author{
Wahyu Ningsih ${ }^{1}$ Lenni $^{2}$ \\ Pendidikan Bahasa dan Sastra Indonesia, Universitas Muhammadiyah Makassar \\ whayuningsih@gmail.com \\ Pendidikan Bahasa dan Sastra Indonesia, Universitas Muhammadiyah Makassar \\ lenni@gmail.co.id
}

\begin{abstract}
This research was a classroom action research (Classroom Reaserch) consisting of two cycles, each cycle of meetings held three times. Research procedured includes planning, action, observation and reflection. Subjects in this study were students of class VIII SMP Negeri 1 Lembang. Data collection techniques used in this research is data about student learning results obtained from the tests during the learning process and observation data through observation sheet.

The results showed that in the first cycle were completed individually of 35 students only 14 students or $56 \%$, which meets the minimum completeness criteria (KKM) or are in the low category. Classically had not been met because the average value obtained at 68.44 , while in the second cycle of 25 students have met KKM and classically been fulfilled with the average value obtained for 81.2 or are at high category which refers to five assessment aspect is the quality of the content of the report, the organization of writing, the precision of diction, use EYD and meaningfulness of the whole text, and the increased activity of students in the learning process in accordance with the results of observations made during the study.

Based on these results above, it can be concluded that the writing skills of students of class VIII SMP Negeri 1 Lembang through the implementation of cooperative learning model Think Talk Write (TTW) has increased.
\end{abstract}

Keywords: writing skills, cooperative Think Talk Write (TTW)

\begin{abstract}
Abstrak
Jenis penelitian ini adalah penelitian tindakan kelas (Class Room Reaserch) yang terdiri dari dua siklus, setiap siklus dilaksanakan sebanyak tiga kali pertemuan. Prosedur penelitian meliputi perencanaan, pelaksanaan tindakan, observasi dan refleksi. Subjek dalam penelitian ini adalah siswa kelas VIII SMP Negeri 1 Lembang. Teknik pengumpulan data yang digunakan dalam penelitian ini adalah data tentang hasil belajar siswa yang diperoleh dari tes pada saat proses pembelajaran dan data hasil pengamatan melalui lembar observasi.

Hasil penelitian menunjukkan bahwa pada siklus I yang tuntas secara individual dari 35 siswa hanya 14 siswa atau 56\% yang memenuhi kriteria ketuntasan minimal (KKM) atau berada pada kategori rendah. Secara klasikal belum terpenuhi karena nilai rata-rata yang diperoleh sebesar 68,44 sedangkan pada siklus II dari 25 siswa telah memenuhi KKM dan secara klasikal sudah terpenuhi dengan nilai rata-rata yang diperoleh sebesar 81,2 atau berada pada kategori tinggi yang mengacu pada lima aspek penilaian yaitu kualitas isi laporan, organisasi penulisan, ketepatan diksi, penggunaan EYD dan kebermaknaan
\end{abstract}


keseluruhan tulisan serta terjadinya peningkatan keaktifan siswa dalam proses belajar mengajar sesuai dengan hasil observasi yang dilakukan selama penelitian. Berdasarkan hasil penelitian tersebut di atas, dapat disimpulkan bahwa keterampilan menulis siswa kelas VIII SMP Negeri 1 Lembang melalui penerapan model pembelajaran kooperatif tipe Think Talk Write (TTW) mengalami peningkatan.

\section{Kata kunci : keterampilan menulis, kooperatif tipe Think Talk Write (TTW)}

\section{Pendahuluan}

Aneka model dan sistem pembelajaran selalu direvisi disesuaikan dengan perkembangan zaman. Hal ini terbukti dengan adanya revisi kurikulum yang dilakukan oleh pemerintah, dalam hal ini yang dilakukan oleh Depdiknas. Sejalan dengan hal tersebut, pencapaian target kurikulum nasional akan berjalan dengan optimal manakala ditunjang dengan metode dan model pembelajaran yang baik dari guru. Artinya guru adalah pusat pendidikan yang berperan penting dalam pelaksanaan pembelajaran di kelas.

Uhar (2013:3), menyatakan bahwa menjadi guru berarti terlibat dalam berbagai kegiatan yang menjadi peran dan tugas dalam proses pendidikan. Pembelajaran menjadi pekerjaan utama yang mau tidak mau harus dilaksanakan dari mulai perencanaan, pelaksanaan, evaluasi dan juga upaya meningkatkan mutu agar pelaksanaan semua tugas semakin hari semakin meningkat, sedangkan Hanis, dkk. (2011:1), menyatakan bahwa bagaimanapun sempurna dan idealnya kurikulum, tanpa dibarengi kemampuan guru untuk mengimplementasikannya, maka kurikulum tersebut akan kurang bermakna. Perubahan kurikulum mungkin hanya bisa diterapkan manakala guru secara profesional memiliki keterampilan dalam pengelolaan pembelajaran atau keterampilan dalam mengajar.

Dalam pembelajaran bahasa dikenal adanya empat keterampilan berbahasa yang perlu dicapai siswa, yaitu keterampilan keterampilan berbicara, keterampilan membaca, dan keterampilan menulis. Keempat keterampilan tersebut saling berhubungan, tidak boleh dipisahpisahkan serta harus dikuasai apabila kita benar-benar ingin menguasai bahasa itu sendiri, karena setiap keterampilan tersebut berhubungan dengan proses berpikir yang mendasari bahasa Indonesia. Oleh karena itu, diperlukan metode ataupun model pembelajaran yang sesuai dari guru sehingga hasil belajar bahasa indonesia peserta didik dapat mengalami peningkatan.

Berdasarkan hasil observasi yang dilakukan di kelas VIII SMP Negeri 1 Lembang Kabupaten pinrang, ditemukan masih banyak kendala yang dialami siswa dalam proses pembelajaran bahasa Indonesia. Khususnya pada keterampilan menulis, banyak dijumpai siswa yang mengeluh karena kesulitan dalam kegiatan menulis laporan. Hal ini disebabkan karena beberapa faktor, antara lain siswa tidak mempunyai tujuan pembelajaran yang jelas, siswa merasa jenuh dan bosan belajar di dalam kelas, siswa tidak senang dengan materi mengungkapkan informasi dalam bentuk laporan yang proses pembelajarannya terkesan monoton, siswa merasa kaku dan tegang dalam mengikuti pembelajaran menulis laporan, kurangnya pengetahuan dan kecakapan siswa dalam mengikuti pembelajaran menulis laporan, terbatasnya kemampuan siswa dalam mengembangkan gagasan atau ide menjadi suatu laporan tertulis baik dalam bentuk laporan perjalanan, peristiwa maupun laporan kegiatan, kemampuan siswa dalam penggunaan kosakata yang 
belum maksimal, penggunaan ejaan dan tanda baca yang masih salah. Selain itu, siswa juga belum bisa memaksimalkan cara menulisnya secara runtut atau memperhatikan kepaduan kalimat dalam laporannya. Kondisi ini yang menyebabkan kemampuan siswa untuk menulis di sekolah tidak berkembang. Hal inilah yang membuat penulis merasa tertarik untuk mengadakan penelitian pada siswa kelas VIII SMP Negeri 1 Lembang karena siswa masih dianggap belum mampu untuk menulis atau nilai yang diperoleh siswa belum mencapai standar yang telah ditentukan, padahal siswa SMP dituntut memenuhi kemampuan yang memadai dalam menulis.

Pemilihan Siswa kelas VIII SMP Negeri 1 Lembang didasari atas pertimbangan sebagaimana siswa di SMP lainnya, bahwa siswa telah mendapat pembelajaran menulis sebagaimana tertera dalam kurikulum yang berlaku, setelah menjalani pembelajaran, siswa dituntut memiliki kemampuan yang memadai dalam menulis dan siswa perlu mendapat pembinaan yang intensif dalam menulis.

Masalah dalam penelitian ini adalah "Bagaimanakah meningkatkan keterampilan menulis melalui model pembelajaran kooperatif tipe Think Talk Write pada siswa kelas VIII SMP Negeri 1 Lembang?".

Penelitian ini bertujuan untuk meningkatkan keterampilan menulis siswa melalui model pembelajaran kooperatif tipe Think Talk Write pada siswa kelas VIII SMP Negeri1 Lembang.

Manfaat penelitian ini adalah menambah khasanah dalam pembelajaran bahasa Indonesia dan bermanfaat dalam meningkatkan keterampilan menulis siswa.

Akhadiah, dkk. (dalam Munirah, 2007: 1) menyatakan bahwa menulis merupakan suatu bentuk komunikasi. Menulis merupakan suatu proses pemikiran yang dimulai dengan pemikiran tentang gagasan yang akan disampaikan, menulis merupakan bentuk komunikasi yang berbeda dengan bercakap-cakap, dalam menulis tidak terdapat intonasi, ekspresi wajah, gerakan fisik serta tidak menyertai percakapan. Menulis merupakan ragam komunikasi yang perlu dilengkapi dengan tanda-tanda penjelas, aturan ejaan serta tanda baca, dan menulis merupakan bentuk komunikasi untuk menyampaikan gagasan penulis kepada khalayak pembaca yang dibatasi oleh jarak, tempat, dan waktu.

Hugo Hartig (dalam Munirah, 2007: 6) merangkum tujuan penulisan sebagai berikut: Tujuan penugasan, tujuan alturistik, tujuan persuasif, tujuan penerangan, tujuan pernyataan diri, tujuan kreatif dan tujuan pemecahan masalah.

Akhadiah, dkk. (dalam Hijrianto, 2008 : 14) berkaitan dengan manfaat menulis mengemukakan bahwa: (1) menulis menyumbang kecerdasan, (2) menulis mengembangkan daya inisiatif dan kreativitas, (3) menulis menumbuhkan keberanian, dan (4) menulis mendorong kemauan dan kemampuan mengumpulkan informasi.

$$
\text { Tarigan }
$$
mengklasifikasikan jenis menulis berdasarkan bentuknya, yaitu : 1) eksposisi yang mencakup definisi dan analisis, 2) deskripsi yang mencakup deskripsi ekspositori dan deskripsi literer, 3) narasi yang mencakup urutan waktu, motif, konflik, titik pandangan, dan pusat minat, 4) argumentasi yang mencakup induksi dan deduksi.

Model pembelajaran kooperatif tipe Think Talk Write (TTW) merupakan model pembelajaran yang didasarkan pada pemahaman bahwa belajar adalah suatu perilaku sosial. Dalam model pembelajaran ini, siswa didorong untuk berpikir, berbicara kemudian menuliskan berkenaan dengan suatu topik. Manula (dalam Erwin,2013:19) mengungkapkan 
bahwa model pembelajaran kooperatif tipe Think Talk Write (TTW) membangun pemikiran, merefleksi, dan mengorganisasi ide, kemudian menguji ide tersebut sebelum siswa diharapkan untuk menulis. Alur model pembelajaran Think Talk Write dimulai dari keterlibatan siswa dalam berpikir atau berdialog reflektif dengan dirinya sendiri, selanjutnya berbicara dan berbagi ide dengan temannya, sebelum siswa menulis.

\section{Metode Penelitian}

Dalam penelitian ini peneliti menggunakan analisis deskriptif kuatitatif dengan perhitungan kategorisasi. Analisis deskriptif dilaksanakan sesuai dengan kecenderungan yang terjadi pada setiap siklus dengan melakukan penilaian secara verbal (aktivitas dan sikap yang teramati atau diambil dari data observasi). Pengkategorian tingkat kemampuan hasil menulis siswa melalui penerapan Model Pembelajaran Kooperatif Tipe Think Talk Write (TTW) dalam ranah kognitif, afektif dan psikomotor.Teknik pengumpulan data yang digunakan dalam penelitian ini adalah data tentang hasil menulis siswa yang diperoleh dari tes pada saat proses pembelajaran ataupun setelah proses pembelajaran yang dapat diperoleh melalui instrumen penelitian.

\section{Hasil Penelitian}

Hasil penelitian yang dilaksanakan di kelas VIII SMP Negeri 1 Lembang mengenai kemampuan menulis laporan perjalanan melalui model pembelajaran kooperatif tipe Think Talk Write (TTW) berlangsung selama dua siklus. Setiap siklus terdiri dari tiga kali pertemuan. Metode pelaksanaan mengikuti prinsip kerja PTK yang terdiri dari empat tahap, yaitu perencanaan, pelaksanaan tindakan, observasi dan refleksi. Data penelitian berupa hasil belajar siswa yang diperoleh dengan melakukan tes evaluasi keterampilan menulis pada akhir siklus I dan siklus II, sedangkan data pendukung berupa aktivitas belajar siswa selama pembelajaran bahasa Indonesia dengan menggunakan model pembelajaran kooperatif TTW sebagai upaya untuk meningkatkan keterampilan menulis siswa kelas VIII SMP Negeri 1 Lembang.

Adapun analisis hasil evaluasi keterampilan menulis siswa kelas VIII SMP Negeri 1 Lembang setelah diterapkan model pembelajaran kooperatif TTW pada siklus I dapat dilihat pada tabel 4.1 sebagai berikut:

\section{Teknik Analisis Data}

Data yang terkumpul dianalisis dengan teknik analisis deskriptif kuatitatif dengan perhitungan kategorisasi . Analisis deskriptif dilaksanakan sesuai dengan kecenderungan yang terjadi pada setiap siklus dengan melakukan penilaian secara verbal (aktivitas dan sikap yang teramati atau diambil dari data observasi). Pengkategorian tingkat kemampuan hasil belajar bahasa Indonesia siswa melalui penerapan Model Pembelajaran Kooperatif Tipe Think Talk Write (TTW) dalam ranah kognitif, afektif dan psikomotor. Kategori untuk menentukan skor yaitu : sangat tinggi, tinggi, sedang, rendah dan sangat rendah. Penentuan kategori atau tabel yang digunakan adalah :

Tabel 4.1 Statistik hasil evaluasi keterampilan menulis siswa siklus 1

\begin{tabular}{cc}
\hline Statistik & Nilai Statistik \\
\hline Subjek & 35 \\
\hline Skor Ideal & 100 \\
\hline Skor tertinggi & 75 \\
\hline Skor terendah & 50
\end{tabular}




\begin{tabular}{cc}
\hline Rentang skor & 25 \\
\hline Skor tara-rata & 61,15 \\
\hline
\end{tabular}

Tabel 4.1 menunjukkan bahwa skor rata-rata keterampilan menulis siswa setelah diadakan tindakan kelas pada siklus 1 dengan nilai rata-rata 68,44 dari skor ideal yang mungkin dicapai yaitu 100. Skor tertinggi 80 dan skor yang terendah 40. Apabila skor keterampilan menulis siswa tersebut dikelompokkan ke dalam 5 kategori berdasarkan kriteria penilaian yang telah ditentukan, maka diperoleh distribusi frekuensi skor seperti ditunjukkan pada tabel berikut :

Tabel 4.2 Distribusi frekuensi hasil evaluasi siswa pada siklus 1

\begin{tabular}{cclcc}
\hline No & Skor & \multicolumn{1}{c}{ Kategori } & Frekuensi & Presentasi \\
\hline 1 & $0-55$ & Sangat Rendah & 13 & $37,15 \%$ \\
\hline 2 & $56-65$ & Rendah & 7 & $20 \%$ \\
\hline 3 & $66-75$ & Sedang & 7 & $20 \%$ \\
\hline 4 & $76-85$ & Tinggi & 8 & $22,86 \%$ \\
\hline 5 & $86-100$ & Sangat Tinggi & 0 & $0 \%$ \\
\hline & Jumlah & & 35 & $100 \%$ \\
\hline
\end{tabular}

Dari tabel 4.2 dapat dilihat bahwa dari 35 siswa kelas VIII SMP Negeri 1 Lembang terdapat $37,15 \%$ hasil keterampilan menulis siswa masuk dalam kategori sangat rendah, terdapat $20 \%$ masuk dalam kategori rendah, $20 \%$ masuk dalam kategori sedang, 22,86 \% masuk dalam kategori tinggi dan $0 \%$ masuk dalam kategori sangat tinggi. Setelah dilaksanakan tindakan kelas (siklus 1). Skor rata-rata keterampilan menulis siswa pada siklus 1 adalah 61,15 dari skor ideal yang mungkin dicapai siswa yaitu berada pada interval 50 sampai 75 dengan demikian dapat disimpulkan bahwa keterampilan menulis siswa kelas VIII SMP Negeri 1 Lembang setelah dilaksanakan pembelajaran dengan menggunakan model pembelajaran kooperatif tipe Think Talk Write (TTW) pada siklus 1 berada pada kategori sedang dan belum mencapai standar ketuntasan $85 \%$ sehingga masih perlu dilaksanakan perencanaan pada siklus II.

Hasil observasi sikap siswa kelas VIII SMP Negeri 1 Lembang selama proses pembelajaran menulis laporan dapat kita lihat pada tabel 4.3 sebagai berikut :

Tabel 4.3 Lembar observasi sikap siswa pada siklus 1

\begin{tabular}{llcr}
\hline NO & \multicolumn{1}{c}{ Keterangan } & Frekuensi & persentase \\
\hline 1 & Siswa yang memenuhi krateria di atas 75 & 9 & $27,72 \%$ \\
\hline 2 & Siswa yang mendapat nilai di bawah krateria 75 & & \\
& & 26 & $74,28 \%$
\end{tabular}

Dari tabel 4.3 dapat dilihat bahwa dari 35 siswa kelas VIII SMP Negeri 1 Lembang terdapat $27,72 \%$ hasil keterampilan menulis siswa masuk dalam kategori sangat rendah dan sangat rendah , masuk dalam kategori sedang, 74,28\% masuk dalam kategori sangat tinggi. Setelah dilaksanakan tindakan kelas (siklus 1). 
Tabel 4.4 Lembar observasi sikap siswa pada siklus 1

\begin{tabular}{|c|c|c|c|c|c|c|}
\hline \multirow[b]{2}{*}{ NO } & \multirow[b]{2}{*}{ Komponen yang Diamati } & \multicolumn{3}{|c|}{ Pertemuan } & \multirow{2}{*}{$\begin{array}{l}\text { Rata- } \\
\text { rata }\end{array}$} & \multirow{2}{*}{$\begin{array}{l}\text { Persentase } \\
\quad(\%)\end{array}$} \\
\hline & & $\bar{I}$ & II & III & & \\
\hline 1 & $\begin{array}{l}\text { Siswa yang hadir pada saat kegiatan } \\
\text { pembelajaran }\end{array}$ & 35 & 28 & 11 & 24 & 68,57 \\
\hline 2 & Siswa yang siap menerima pelajaran & 8 & 10 & 12 & 10 & 28,57 \\
\hline 3 & $\begin{array}{l}\text { Siswa yang memperhatikan dengan } \\
\text { serius pada saat proses pembelajaran }\end{array}$ & 8 & 6 & 12 & 8,67 & 24,78 \\
\hline 4 & $\begin{array}{l}\text { Siswa yang termotivasi dalam mengikuti } \\
\text { proses belajar mengajar }\end{array}$ & 5 & 8 & 12 & 8,33 & 23,8 \\
\hline 5 & $\begin{array}{l}\text { Siswa yang aktif pada tahap Think } \\
\text { (berpikir) dalam kegiatan pembelajaran. }\end{array}$ & 5 & 4 & 8 & 5,6 & 16 \\
\hline 6 & $\begin{array}{l}\text { Siswa yang aktif pada tahap Talk } \\
\text { (berbicara) dalam kegiatan } \\
\text { pembelajaran. }\end{array}$ & 5 & 2 & 6 & 4,3 & 12,29 \\
\hline 7 & $\begin{array}{l}\text { Siswa yang aktif pada tahap Write } \\
\text { (menulis) laporan sesuai dengan waktu } \\
\text { yang ditentukan. }\end{array}$ & 6 & 8 & 12 & 8,67 & 24,77 \\
\hline
\end{tabular}

Hasil Tabel 4.4 pelaksanaan tindakan siklusi I pertemuan I dianggap belum berhasil karena siswa masih baru dengan penerapan model pembelajaran kooperatif tipe think talk write sehingga aktifitas belajar siswa masih kurang maksimal. Hal tersebut dapat dilihat dari jumlah siswa yang hadir mencapai ratarata 34 atau $68,57 \%$, siswa yang siap menerima pelajaran pada saat kegiatan pembelajaran berlangsung rata-rata 10 atau $28,57 \%$, siswa yang memperhatikan dengan serius ketika berlangsungnya proses pembelajaran rata-rata 8,67 atau $24,78 \%$, siswa yang termotivasi dalam mengikuti kegiatan pembelajaran rata-rata 8,33 atau $23,8 \%$, siswa yang aktif pada tahap Think (berpikir) dalam kegiatan pembelajaran rata-rata 5,6 atau $16 \%$, siswa yang aktif pada tahap Talk (berbicara) dalam kegiatan pembelajaran rata-rata 4,3 dengan persentase 12,29\% dan siswa yang aktif pada tahap Write (menulis) laporan perjalanan sesuai dengan waktu yang ditentukan rata-rata 8,67 atau $24,77 \%$. Hal tersebut menunjukkan bahwa aktifitas belajar dan sikap siswa dalam kegiatan pembelajaran masih kurang.

Adapun analisis hasil evaluasi keterampilan menulis siswa kelas VIII SMP Negeri 1 Lembang pada siklus II dapat dilihat pada tabel 4.4 sebagai berikut:

Tabel 4.4 Statistik hasil evaluasi keterampilan menulis siswa siklus II

\begin{tabular}{cc}
\hline Statistik & Nilai Statistik \\
\hline Subjek & 35 \\
\hline Skor Ideal & 100 \\
\hline
\end{tabular}




\begin{tabular}{cc}
\hline Skor tertinggi & 85 \\
\hline Skor terendah & 70 \\
\hline Rentang skor & 15 \\
\hline Skor tara-rata & 74,58 \\
\hline
\end{tabular}

Tabel 4.4 menunjukkan bahwa skor rata-rata keterampilan menulis siswa setelah diadakan tindakan kelas pada siklus 1I dengan nilai rata-rata 74,58 dari skor ideal yang mungkin dicapai yaitu 100. Skor tertinggi 85 dan skor yang terendah 70. Apabila skor keterampilan menulis siswa tersebut dikelompokkan ke dalam 5 kategori berdasarkan kriteria penilaian yang telah ditentukan, maka diperoleh distribusi frekuensi skor seperti ditunjukkan pada tabel berikut :

Tabel 4.5 Distribusi frekuensi hasil evaluasi siswa pada siklus 1I

\begin{tabular}{cclcc}
\hline No & Skor & \multicolumn{1}{c}{ Kategori } & Frekuensi & Presentasi \\
\hline 1 & $0-55$ & Sangat Rendah & 0 & $0 \%$ \\
\hline 2 & $56-65$ & Rendah & 0 & $0 \%$ \\
\hline 3 & $66-75$ & Sedang & 11 & $31,42 \%$ \\
\hline 4 & $76-85$ & Tinggi & 24 & $68,57 \%$ \\
\hline 5 & $86-100$ & Sangat Tinggi & 0 & $0 \%$ \\
\hline & Jumlah & & 35 & $100 \%$ \\
\hline
\end{tabular}

Dari tabel 4.5 dapat dilihat bahwa dari 35 siswa kelas VIII. SMP Negeri 1 Lembang terdapat $0 \%$ hasil keterampilan menulis siswa masuk dalam kategori sangat rendah, terdapat $0 \%$ masuk dalam kategori rendah, 31,42\% masuk dalam kategori sedang, 68,57 \% masuk dalam kategori tinggi dan $0 \%$ masuk dalam kategori sangat tinggi setelah dilaksanakan tindakan kelas (siklus 1I).

Tabel 4.6 Distribusi Frekuensi dan Persentasi Hasil Evaluasi siswa pada Siklus I dan Siklus 11

\begin{tabular}{cccccc}
\hline \multirow{2}{*}{ No $\begin{array}{c}\text { Interval } \\
\text { Skor }\end{array}$} & Kategori & \multicolumn{2}{c}{ Frekuensi } & \multicolumn{2}{c}{ Persentase \% } \\
\cline { 3 - 6 } & & Siklus I & Siklus II & Siklus I & Siklus II \\
\hline $0-39$ & Sangat Rendah & 13 & 0 & $37,15 \%$ & $0 \%$ \\
\hline $40-54$ & Rendah & 7 & 0 & $20 \%$ & $0 \%$ \\
\hline $55-69$ & Sedang & 7 & 11 & $20 \%$ & $31,42 \%$ \\
\hline $75-84$ & Tinggi & 8 & 24 & $22,86 \%$ & $68,57 \%$ \\
\hline $85-100$ & Sangat Tinggi & 0 & 0 & $0 \%$ & $0 \%$ \\
\hline \multicolumn{2}{c}{ Jumlah } & 35 & 35 & $100 \%$ & $100 \%$ \\
\hline
\end{tabular}

Berdasarkan tabel 4.6 di atas, dapat diketahui bahwa terjadi peningkatan menulis pada siswa kelas VIII SMP Negeri 1 Lembang dari siklus I ke siklus II, yaitu pada siklus I hasil evaluasi keterampilan menulis siswa berada pada kategori sedang dengan nilai rata-rata 61,15 kemudian pada siklus II meningkat dengan nilai rata-rata yang diperoleh siswa 74,58 berada pada kategori tinggi. Dengan demikian dapat disimpulkan bahwa keterampilan menulis siswa kelas VIII SMP Negeri 1 Lembang setelah diajar dengan menggunakan model pembelajaran kooperatif tipe Think Talk Write (TTW) mengalami peningkatan. 
Data tentang sikap siswa kelas VIII SMP Negeri 1 Lembang selama mengikuti pelajaran Bahasa Indonesia pada siklus II ditunjukkan dalam tabel 4.7 tentang hasil observasi sikap siswa selama proses pembelajaran.

Tabel 4.7 lembar observasi yang memenuhi krateria di atas 75 siswa pada siklus II

\begin{tabular}{llcc}
\hline NO & \multicolumn{1}{c}{ Keterangan } & Frekuensi & persentase \\
\hline 1 & Siswa yang memenuhi krateria di atas 75 & 31 & $88,57 \%$ \\
\hline 2 & Siswa yang mendapat nilai di bawah krateria 75 & & \\
& & 4 & $11,43 \%$
\end{tabular}

Dari tabel 4.7 dapat dilihat bahwa dari 35 siswa kelas VIII SMP Negeri 1 Lembang terdapat $88,57 \%$ hasil keterampilan menulis siswa masuk dalam kategori tinggi dan, masuk dalam kategori sedang, 11,43\% masuk dalam kategori sangat tinggi. Setelah dilaksanakan tindakan kelas (siklus 11).

Tabel 4.8 Lembar observasi sikap siswa pada siklus II

\begin{tabular}{|c|c|c|c|c|c|c|}
\hline \multirow[b]{2}{*}{ NO } & \multirow[b]{2}{*}{ Komponen yang Diamati } & \multicolumn{3}{|c|}{ Pertemuan } & \multirow{2}{*}{$\begin{array}{l}\text { Rata- } \\
\text { rata }\end{array}$} & \multirow{2}{*}{$\begin{array}{l}\text { Persentase } \\
\quad(\%)\end{array}$} \\
\hline & & $\mathbf{I}$ & II & III & & \\
\hline 1 & $\begin{array}{l}\text { Siswa yang hadir pada saat kegiatan } \\
\text { pembelajaran }\end{array}$ & 35 & 28 & 11 & 24 & 68,57 \\
\hline 2 & Siswa yang siap menerima pelajaran & 8 & 10 & 12 & 10 & 28,57 \\
\hline 3 & $\begin{array}{l}\text { Siswa yang memperhatikan dengan } \\
\text { serius pada saat proses pembelajaran }\end{array}$ & 8 & 6 & 12 & 8,67 & 24,78 \\
\hline 4 & $\begin{array}{l}\text { Siswa yang termotivasi dalam mengikuti } \\
\text { proses belajar mengajar }\end{array}$ & 5 & 8 & 12 & 8,33 & 23,8 \\
\hline 5 & $\begin{array}{l}\text { Siswa yang aktif pada tahap Think } \\
\text { (berpikir) dalam kegiatan pembelajaran. }\end{array}$ & 5 & 4 & 8 & 5,6 & 16 \\
\hline 6 & $\begin{array}{l}\text { Siswa yang aktif pada tahap Talk } \\
\text { (berbicara) dalam kegiatan } \\
\text { pembelajaran. }\end{array}$ & 5 & 2 & 6 & 4,3 & 12,29 \\
\hline 7 & $\begin{array}{l}\text { Siswa yang aktif pada tahap Write } \\
\text { (menulis) laporan sesuai dengan waktu } \\
\text { yang ditentukan. }\end{array}$ & 6 & 8 & 12 & 8,67 & 24,77 \\
\hline
\end{tabular}


Pada siklus 1I, semangat siswa dalam mengikuti pelajaran Bahasa Indonesia melalui model pembelajaran kooperatif tipe Think Talk Write (TTW) mengalami peningkatan. Hal tersebut dapat dilihat dari jumlah siswa yang hadir mencapai rata-rata 23,3 atau $93,2 \%$, siswa yang siap menerima pelajaran pada saat rata-rata 17,33 atau $69,32 \%$, siswa yang memperhatikan dengan serius ketika ketika berlangsungnya proses pembelajaran rata-rata 15,3 atau $61,2 \%$, siswa yang termotivasi dalam mengikuti proses pembelajaran rata-rata 14,33 atau $57,32 \%$, siswa yang aktif pada tahap Think (berpikir) dalam kegiatan pembelajaran rata-rata 9,3 atau 37,2\%, siswa yang aktif pada tahap Talk (berbicara) dalam kegiatan pembelajaran rata-rata 13,3 atau $53,2 \%$ dan siswa yang aktif pada tahap Write (menulis) laporan perjalanan sesuai dengan waktu yang ditentukan rata-rata 12,6 atau 50,4\%. Hal tersebut menunjukkan bahwa aktifitas belajar dan sikap siswa dalam kgiatan pembelajaran mengalami perubahan yang baik.

\section{SIMPULAN DAN SARAN}

1. Model pembelajaran kooperatif tipe Think Talk Write (TTW) dapat meningkatkan keterampilan menulis siswa kelas VIII SMP Negeri 1 Lembang. Pada siklus I nilai rata-rata keterampilan menulis yang diperoleh siswa sebesar 68,44 atau $20 \%$ berada pada kategori sedang. dan pada siklus II meningkat menjadi 81,2 atau $64 \%$ berada pada kategori tinggi, serta 9 orang siswa atau $36 \%$ mencapai nilai pada kategori sangat tinggi.

2. Hasil observasi menunjukkan bahwa penerapan model pembelajaran kooperatif tipe Think Talk Write (TTW) dapat meningkatkan aktivitas belajar dan sikap siswa dalam kegiatan pembelajaran menulis laporan. Hal ini dapat dilihat dengan terjadinya peningkatan yang signifikan dari siklus I ke siklus II, tingkat kehadiran siswa, kesiapan siswa menerima pelajaran, perhatian siswa terhadap pelajaran, keaktifan siswa dalam bekerjasama dan kemampuan siswa dalam menulis laporan sesuai dengan waktu yang ditentukan mengalami peningkatan atau perubahan yang sangat baik.

Upaya untuk meningkatkan keterampilan menulis siswa, peneliti mengajukan beberapa saran sebagai berikut:

1. Diharapkan kepada guru Bahasa Indonesia untuk memberikan motivasi yang lebih tinggi terhadap siswa-siswa yang kurang berani mengutarakan pendapat atau menuangkan gagasannya dalam bentuk tulisan.

2. Upaya mencapai tujuan pembelajaran diharapkan para guru hendaknya lebih sabar dalam menghadapi para siswa dalam proses pembelajaran, terutama pada kemampuan tingkat rendah.

3. Guru Bahasa Indonesia harus lebih membimbing siswa untuk bekarja dan belajar secara kooperatif, agar siswa-siswa kelompok tidak acuh tak acuh terhadap tugas.

4. Agar siswa mampu memhami materi pelajaran, hendaknya siswa bersungguh-sungguh dalam menerima pelajaran dan aktif bertanya apabila mengalami kesulitan untuk memahaminya. 
DAFTAR PUSTAKA

Hanis, dkk. 2011. Keterampilan Dasar dalam Proses Pembelajaran. Makassar : Unismuh Makassar Press.

Hijrianto. 2008. Peningkatan Kemampuan Menulis Deskripsi Siswa Kelas X SMA Negeri 1 Bajeng Kabupaten Gowa . Skripsi. Tidak diterbitkan. Makassar. Program Studi Starata Satu (S1) Unismuh Makassar

Munirah. 2007. Dasar Keterampilan

Menulis ( Diktat) Makassar :

FKIP Unismuh Makassar.

Erwin. 2013. Penerapan Model Pembelajaran Kooperatif Tipe Think Talk Write (TTW) untuk Meningkatkan Hasil Belajar IPS Geografi Siswa Kelas VII SMP Negeri 33 Makassar. Skripsi. Tidak diterbitkan. Makassar. Program Studi Pendidikan Geografi. Universitas Negeri Makassar.

Suharsaputra, Uhar. 2013. Menjadi Guru Berkarakter. Bandung : PT. Refika Aditama.

Tarigan, Henry Guntur. 2008. Menulis Sebagai Suatu Keterampilan Berbahasa. Bandung: Angkasa. 